\title{
Elemental Compositions of Some Eye Shadow Products Marketed in Saudi Arabia
}

\author{
Faten M. Ali Zainy ${ }^{1,2^{*}}$, Fatima Bannani1,2, Ohoud A. Alotaibi, ${ }^{1,2}$ \\ ${ }^{1}$ Department of Chemistry, Faculty of Science, King Abdulaziz University, Jeddah, KSA \\ ${ }^{2}$ Department of Chemistry, Faculty of Science, Jeddah University, Jeddah, KSA \\ Email: ^fzainalabdeen@kau.edu.sa
}

How to cite this paper: Zainy, F.M.A., Bannani, F. and Alotaibi, O.A. (2018) Elemental Compositions of Some Eye Shadow Products Marketed in Saudi Arabia. Journal of Cosmetics, Dermatological Sciences and Applications, 8, 236-243. https://doi.org/10.4236/jcdsa.2018.84024

Received: September 10, 2018

Accepted: December 3, 2018

Published: December 6, 2018

Copyright (๑) 2018 by authors and Scientific Research Publishing Inc. This work is licensed under the Creative Commons Attribution International License (CC BY 4.0).

http://creativecommons.org/licenses/by/4.0/

(c) (i) Open Access

\begin{abstract}
This study focuses on the determination, as well as, the composition of some heavy metals contained in 12 eye shadow cosmetic samples. An elemental analysis of heavy metals ( $\mathrm{Ti}, \mathrm{Cr}, \mathrm{Fe}, \mathrm{Ni}, \mathrm{Cu}, \mathrm{Co}, \mathrm{Mn}, \mathrm{Pb}$, and $\mathrm{Zn}$ ) was performed by X-ray Fluorescence. The constitution of some samples was studied by Powder X-Ray Diffraction. Heavy metals exist as zinc oxide, Titanium dioxide, Iron oxide, Bismuth oxychloride, and lead sulfide. The quantification of selected toxic heavy metals lead, copper and nickel were achieved by Inductively Coupled Plasma-Optical Emission Spectrometry after digestion with concentrated acids. In all analyzed samples lead had a concentration less than $20 \mathrm{ppm}$, which indicated good manufacturing practice. Copper and nickel levels were within acceptable concentrations, but overpasses the safe limit appeared in China samples. The prolonged use of cosmetics case an allergic problem for consumers. Therefore, quality controls are highly controlled for imported products with different regulations.
\end{abstract}

\section{Keywords}

Cosmetic, Eye Shadow, Heavy Metals, ICP, XRD, XRF

\section{Introduction}

Cosmetic products since ancient civilizations were indicated the power and beautiful [1]. Many found Egyptian burial furniture consisting of containers filled with makeup dated from 1200 BC [2]. Since cosmetics are daily used by millions of consumers from all over the world, the security of these products and their components has drawn raising consideration due to their toxicology evaluation [3]. Several studies have revealed that some used materials can penetrate human skin and cause many problems; this leads to improve the analysis of cosmetic products ingredients besides examination of their possible regular tox- 
icity [4]. Some metals are added on purpose as ingredients, whereas others are impurities. Applying to metals has been joined to health concerns including reproductive disorders, immune and nervous system toxicity. A group, heavy metals like arsenic (As), chromium $(\mathrm{Cr})$, nickel $(\mathrm{Ni})$, lead $(\mathrm{Pb})$, cobalt $(\mathrm{Co})$, copper $(\mathrm{Cu})$, and $\mathrm{Zi}-\mathrm{Nc}(\mathrm{Zn})$ can cause an adverse effect. Ingested or inhaled heavy metal will cause poisoning in the form of various diseases [5]. Lead venenosity is an international problem, it is one of the great environmental diseases in pregnant women and children even the exposure to low levels of it [6] [7]. Since cosmetic products are very used by women in Saudi Arabia, these cosmetics contain various chemicals which include heavy metals. The latter are known to be responsible for many allergic problems and health risk to consumers. This study is a target to the determination for heavy metals concentrations and detection of some dangerous components in eye makeup (eye shadow) available in the Saudi market using XRF, XRD and ICP techniques.

\section{Experimental}

\subsection{Materials and Methods}

A total of 12 samples of eye shadow makeup were selected from products available in the shops at Jeddah markets in Saudi Arabiain May 2016. Samples were chosen depending on the results of the questionnaire for Saudi women about the most brands they use. The analyzed colored eye shadow samples were divided into 4 groups, manufactured in different countries. Three of the selected samples were locally manufactured while the 9 others were produced in China, Italy, Canada, and USA. To achieve this work many techniques were used for analysis, included; ICP-OES, X-Ray Fluorescence (XRF) for quantitative multi-elemental analysis, X-Ray Powder Diffraction (XRD) to investigate the structural information on the crystalline content.

\subsection{Powder X-Ray Diffraction PXRD}

Sample Analysis: powdered eye shadow samples were analyzed using a Powder XRD diffractometer (Model Equinox1000 - INEL (France) with Co $\mathrm{K} \alpha(\lambda=$ $1.7890 \AA$ ) radiation at $30 \mathrm{kV}$ and $30 \mathrm{~mA}$. Minimal eye shadow powder sample was preparation, fixed into sample holders and located into the instrument. Sample was scanned over a $2 \theta$ range $0^{\circ}-120^{\circ}$. PXRD data was used to detect the crystalline phases present in the samples and comparing them to the ICDD (International Centre for Diffraction Data) database. Data Processing: To describe the components that present in eye shadow samples, MATCH software (Ver. 12.0, Crystal Impact, Germany) was used to achieve a search/match analysis by balance sample diagram to reference diagram from an ICDD Powder Diffraction Files (PDF) and COD (Crystallographic Open Databases) databases.

\subsection{Energy Dispersive X-Ray Fluorescence Spectrometry EDXRF}

For EDXRF analysis, finely grounded powder was mounted in sample cups. Dif- 
fraction data were collected by Amptek spectrometer with X-123 Silicon Drift Detector SDD and $22 \mathrm{KeV}$ Ag X-Ray source $(50 \mathrm{KV}, 60 \mathrm{uA})$. These data were used to determine the elemental composition, as percent by weight of the element, present in samples. The detection was qualitative and the elemental range covered all elements from Si to UU.

\subsection{ICP-OES}

Reagents and standards: Great pureness $\mathrm{HNO}_{3}$ and $\mathrm{HClO}_{4}(65 \%-60 \%$, Sigma Aldrich) were adjusted to digesting the eye shadow samples [8]. Calibration curve for every heavy metal (stock standards of ICP-OES-68B Solution A, 100 $\mathrm{mg} / \mathrm{L}$ in $4 \% \mathrm{HNO}_{3}$ in the field of (0.5 to $10 \mathrm{ppm}$ ) were created daily, dilution correction was applied. Sample preparation and analysis: followed precedent issued methods [9] [10]. Accurate assessment of heavy metal concentration in eye shadow products is very considerable due to close range betwixt toxic and safe levels. This study made use of ICP-OES (Perkin Elmer-Optima 7300DV) for copper, nickel and lead. The situation for the ICP-OES work was: power, 1550 $\mathrm{W}$; plasma gas, $15 \mathrm{~L} / \mathrm{min}$; aux gas, $0.2 \mathrm{~L} / \mathrm{min}$; nebulizer, $0.8 \mathrm{~L} / \mathrm{min}$; sampling rate, $0.3 \mathrm{~mL} / \mathrm{min}$. The analysis was performed in triplicate, standard deviation was calculate.

\section{Results and Discussions}

Lead concentration is summarized in (Table 1). The results range from 1.2 $\mu \mathrm{g} \cdot \mathrm{g}^{-1}$ (S6) to $16.6 \mu \mathrm{g} \cdot \mathrm{g}^{-1}$ (S3).

Samples S5 and S8 are lead-free. The analyzed samples had content of lead less than $20 \mu \mathrm{g} \cdot \mathrm{g}^{-1}$, which represents the highest lead limit as contaminant in color additives in the cosmetics for outer treatment, according to US FDA (United

Table 1. Concentration of $\mathrm{Pb}$ in eye shadow samples $\left(\mu \mathrm{g} \cdot \mathrm{g}^{-1}\right)$.

\begin{tabular}{ccccc}
\hline Brand & Sample no. & Origin country & Colour & $\mathrm{Pb}$ \\
\hline \multirow{2}{*}{1} & S1 & & Black & $4 \pm 0.01$ \\
& S2 & China & Blue & $10.4 \pm 0.01$ \\
& S3 & & Brown & $16.6 \pm 0.04$ \\
& S4 & & Black & $7.6 \pm 0.11$ \\
& S5 & Saudi Arabia & Blue & ND \\
& S6 & & Brown & $1.2 \pm 0.04$ \\
& S7 & & Black & $9.2 \pm 0.07$ \\
& S8 & China & Blue & ND \\
& S9 & & Brown & $2.8 \pm 0.02$ \\
& S10 & Italy & Black & $3.8 \pm 0.05$ \\
& S11 & Canada & Blue & $7.8 \pm 0.00$ \\
& S12 & U.S.A & Brown & $4.6 \pm 0.03$ \\
\hline
\end{tabular}

$(\mathrm{ND}=$ Not Detectable $)$. 
States Food and Drugs Administration), but exceeds the limits of SASO (Saudi Standards, Metrology and Quality Org.) and health Canada organisms which limits are $10 \mathrm{ppm}$ (Table 2). The maximum amounts in eye shadows reported for $\mathrm{Pb}$ are 41.1 [11], 58.7 [12] and $81.5 \mu \mathrm{g} \cdot \mathrm{g}^{-1}$ [13].

The concentrations of copper and nickel are showed in (Table 3). Copper amount ranges from $0.6 \mu \mathrm{g} \cdot \mathrm{g}^{-1}$ (S5) to $337.4 \mu \mathrm{g} \cdot \mathrm{g}^{-1}$ (S2). 6 out of 12 samples had undetectable cupper level. The highest value corresponds to eye shadow sample

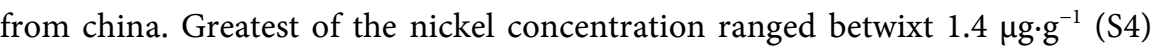
and $14.8 \mu \mathrm{g} \cdot \mathrm{g}^{-1}$ (S11). The maximum levels in eye shadows reported for $\mathrm{Ni}$ is $49.7 \mu \mathrm{g} \cdot \mathrm{g}^{-1}$. Hopefully, the levels of heavy metals obtained from the present work are below results obtained from precedent studies [16].

In order to minimize allergic risks related to cosmetic products use, preferred amounts of heavy metals represent as copper and nickel are less than $5 \mu \mathrm{g} \cdot \mathrm{g}^{-1}$ [17] [18] [19]. Analyzed sample results had copper and nickel levels largely

Table 2. Recommended limits and toxicity for some metals.

\begin{tabular}{|c|c|c|c|c|c|}
\hline & & $\mathrm{Cu}$ & $\mathrm{Ni}$ & $\mathrm{Pb}$ & Refs. \\
\hline \multirow{3}{*}{$\begin{array}{l}\text { Recommended } \\
\text { limits }\end{array}$} & SASO & - & - & $10 \mu \mathrm{g} \cdot \mathrm{g}^{-1}$ & [14] \\
\hline & FDA & - & - & $20 \mu \mathrm{g} \cdot \mathrm{g}^{-1}$ & [7] \\
\hline & $\begin{array}{l}\text { Health } \\
\text { Canada }\end{array}$ & - & - & $10 \mu \mathrm{g} \cdot \mathrm{g}^{-1}$ & [7] \\
\hline Toxicities & & $\begin{array}{l}\text { Liver damage, } \\
\text { insomnia, } \\
\text { Wilson disease }\end{array}$ & $\begin{array}{l}\text { dermatitis, nausea, } \\
\text { chronic asthma, } \\
\text { coughing, a } \\
\text { human carcinogen }\end{array}$ & $\begin{array}{l}\text { fetal brain damage, } \\
\text { kidney disease, } \\
\text { circulatory system, } \\
\text { nervous system, and } \\
\text { autoimmunity problems }\end{array}$ & [15] \\
\hline
\end{tabular}

Table 3. Copper and Nickel concentrations in eye shadow samples $\left(\mu g \cdot g^{-1}\right)$.

\begin{tabular}{ccc}
\hline Sample No. & Copper & Nickel \\
S1 & $167 \pm 0.01$ & $2.8 \pm 0.00$ \\
S2 & $337.4 \pm 0.02$ & $10.2 \pm 0.01$ \\
S3 & $7.2 \pm 0.00$ & $10.2 \pm 0.02$ \\
S4 & ND & $1.4 \pm 0.00$ \\
S5 & $0.6 \pm 0.00$ & $6 \pm 0.01$ \\
S6 & $4.4 \pm 0.00$ & $11.8 \pm 0.01$ \\
S7 & ND & $0.8 \pm 0.00$ \\
S8 & ND & ND \\
S9 & ND & $8 \pm 0.00$ \\
S10 & ND & ND \\
S11 & ND & $14.8 \pm 0.01$ \\
S12 & No.00 & $6.6 \pm 0.017$ \\
\hline
\end{tabular}

$(\mathrm{ND}=$ Not Detectable) 
under this limit, so they consider as harmless and safe. However, several Chinese samples had a concentration of copper and nickel over this limit. XRF instrument usually used to detect many elements of cosmetic products [20]. The XRF analysis of the 12 eye-shadow samples reveals the presence of heavy metals: $\mathrm{Ti}$, $\mathrm{Cr}, \mathrm{Fe}, \mathrm{Ni}, \mathrm{Cu}, \mathrm{Co}, \mathrm{Mn}, \mathrm{Pb}$, and Znas mentioned in (Figure 1). The XRD pattern of the twelve samples is presented in (Figure 2), S11-S12 examined samples, are Bismuth containing. These samples are manufactured in Canada and USA respectively. Energy Dispersive X-Ray Fluorescence Spectrometry EDXRF pattern of sample S11 is presented in (Figure 3).

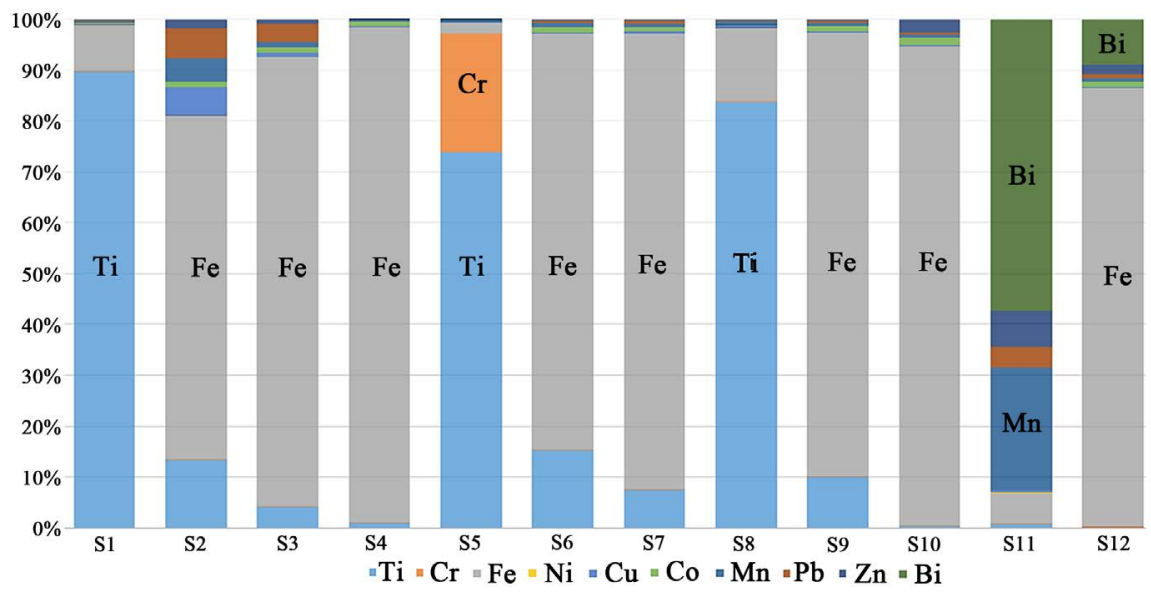

Figure 1. Summary of XRF results of the 12 eye-shadow samples.

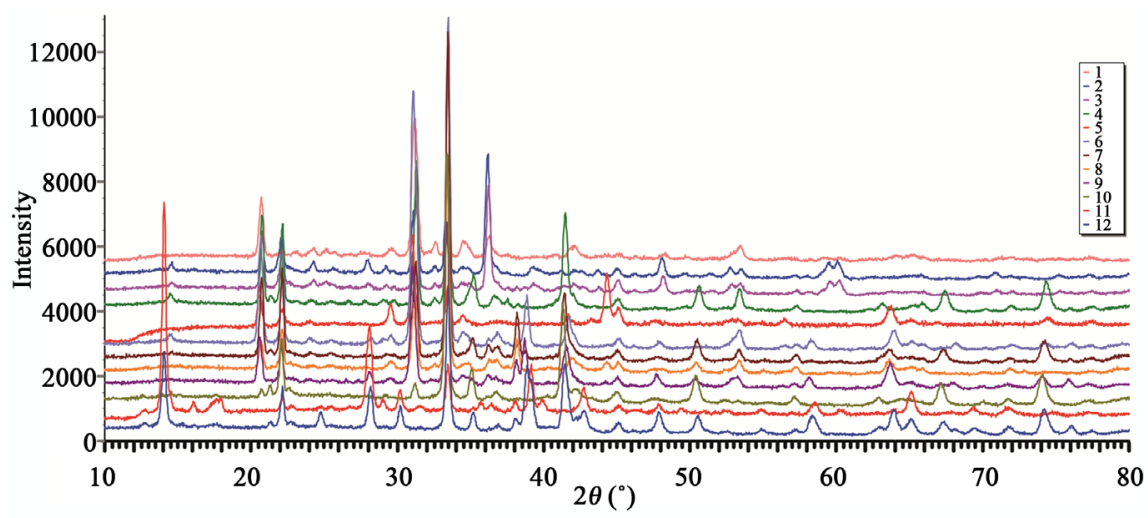

Figure 2. XRD patterns of the 12 eye shadow samples.

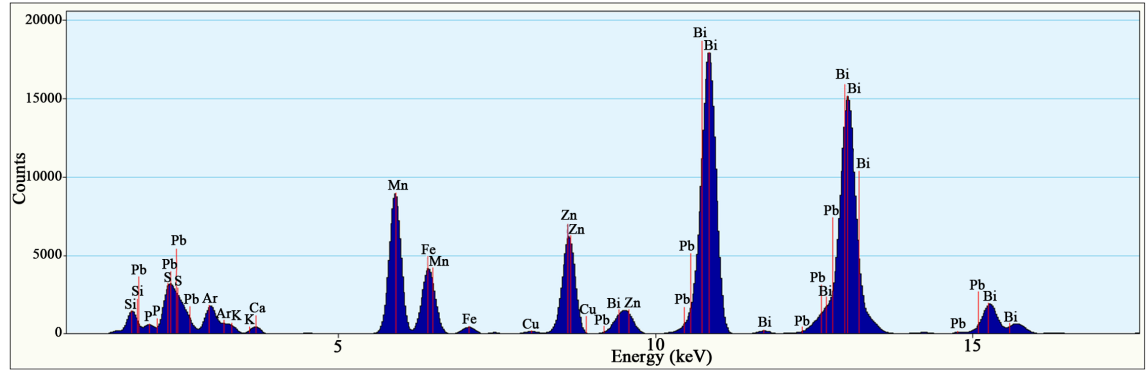

Figure 3. EDXRF pattern of sample S11. 
$\mathrm{Bi}$ is identified at levels of product weight as $47.65 \%$ in S11 and $8.47 \%$ in $\mathrm{S} 12$ (Table 4). Bi is joined with the additive $\mathrm{BiOCl}$ as evidenced by XRD. The diffraction pattern as diffraction peaks match those of $\mathrm{BiOCl}$ at $2 \theta$ angles $13.94^{\circ}$, $28.1^{\circ}, 30.14^{\circ}, 37.87^{\circ}$ and 39.7. (ICDD, PDF number 01-085-0861). The phase identification in S11 sample is shown in (Figure 4). BiOCl which is used in cosmetics and known as a skin irritant. Iron is present in all samples with different concentrations. Fe levels of product weight range from $1.69 \%$ to $82.9 \%$ (Table $4)$.

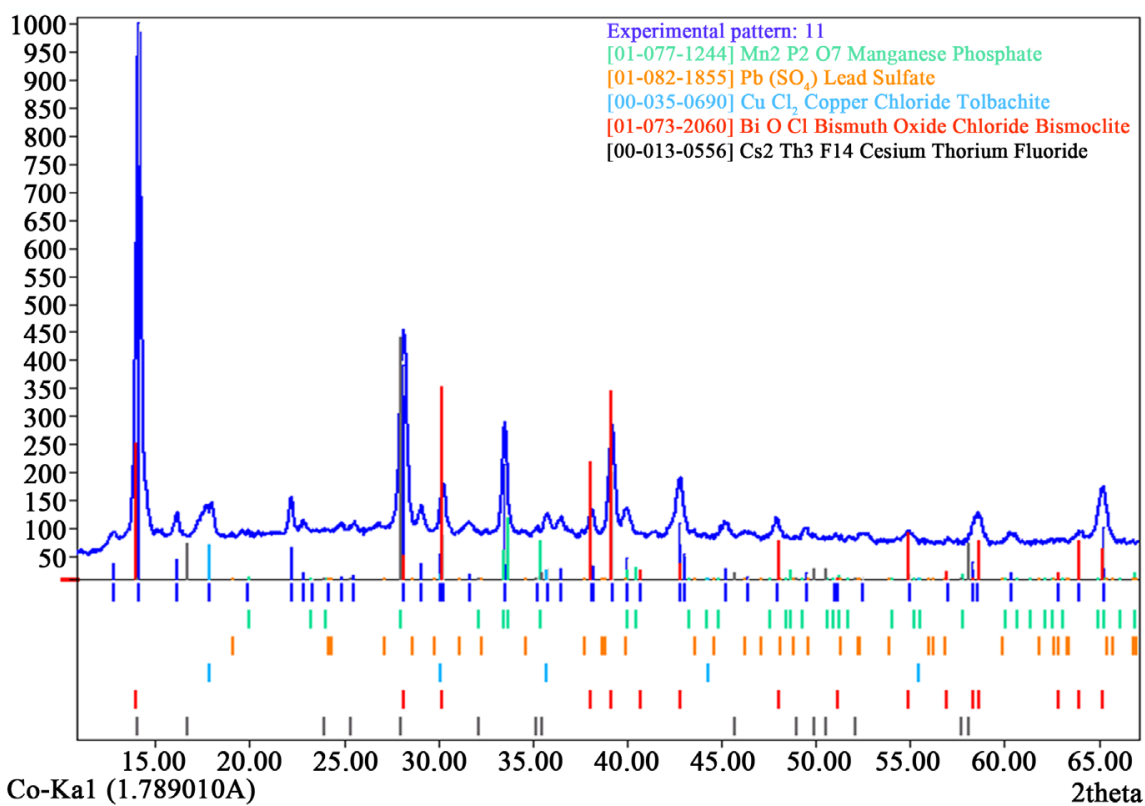

Figure 4. XRD pattern of $S 11$ with phase identification.

Table 4. XRF \% weight composition.

\begin{tabular}{ccccccccccc}
\hline Sample & $\mathrm{Ti}$ & $\mathrm{Cr}$ & $\mathrm{Fe}$ & $\mathrm{Ni}$ & $\mathrm{Cu}$ & $\mathrm{Co}$ & $\mathrm{Mn}$ & $\mathrm{Pb}$ & $\mathrm{Zn}$ & $\mathrm{Bi}$ \\
\hline $\mathrm{S} 1$ & 47.5 & 0.016 & 4.85 & 0.0355 & 0.0906 & 0.072 & 0.095 & 0.174 & 0.148 & 0 \\
$\mathrm{~S} 2$ & 0.928 & 0.00054 & 4.7 & 0.00051 & 0.3899 & 0.076 & 0.323 & 0.398 & 0.1272 & 0 \\
$\mathrm{~S} 3$ & 0.65 & 0.00134 & 14.35 & 0 & 0.137 & 0.1921 & 0.168 & 0.58 & 0.15 & 0 \\
S4 & 0.62 & 0.05 & 66.33 & 0 & 0.024 & 0.69 & 0.18 & 0.015 & 0.1 & 0 \\
S5 & 60.14 & 19.12 & 1.69 & 0 & 0.064 & 0.05 & 0.316 & 0.047 & 0.058 & 0 \\
S6 & 9.6 & 0.003 & 51.84 & 0 & 0.1 & 0.7 & 0.42 & 0.351 & 0.163 & 0 \\
S7 & 5.6 & 0.02 & 68.1 & 0 & 0.22 & 0.754 & 0.469 & 0.413 & 0.265 & 0 \\
S8 & 44.6 & 0.0313 & 7.68 & 0.036 & 0.23 & 0.09 & 0.3 & 0.164 & 0.1139 & 0 \\
S9 & 7.09 & 0.0432 & 62.85 & 0 & 0.162 & 0.81 & 0.32 & 0.38 & 0.213 & 0 \\
S10 & 0.18 & 0.05 & 82.9 & 0 & 0.169 & 1.26 & 0.615 & 0.316 & 2.368 & 0 \\
S11 & 0.56 & 0.08 & 5.02 & 0.207 & 0.256 & 0 & 20.17 & 3.26 & 5.85 & 47.65 \\
S12 & 0.13 & 0.04 & 82.6 & 0 & 0.172 & 1.1 & 0.535 & 0.785 & 1.88 & 8.47 \\
\hline
\end{tabular}


Greatest levels were detected in dark Italian and American samples S10 and S12. The iron-based sample, contained hematite $\left(\mathrm{Fe}_{2} \mathrm{O}_{3}\right)$ has assigned by PXRD results. The search matched diffraction patterns of iron oxide $\mathrm{Fe}_{2} \mathrm{O}_{3}$, titanium dioxide $\mathrm{TiO}_{2}$, bismuth oxychloride, zinc oxide $\mathrm{ZnO}$, and lead sulfide $\mathrm{PbS}$ to sample diffraction pattern in the structure of Hematite, anatase, $\mathrm{BiOCl}$, zincite, and Galena respectively. Compared these results to the relative elemental concentrations of zinc, titanium and $\mathrm{Fe}, \mathrm{Bi}$ and $\mathrm{Pb}$ obtained by XRF analysis.

\section{Conclusion}

The amounts of heavy metals in various eye shadow products were achieved by $\mathrm{X}$-ray Fluorescence and ICP-OES in this work. The composition of some samples was studied by PXRD. The overall results of these study reported that heavy metals present in eye shadow are within acceptable limits while some of those imported from China can be harmful, the prolonged use of such products can be a potential threat to human health since heavy metals can accumulate in human tissues over time and induce allergic problems. To minimize health risks related to cosmetic products use, it is highly recommended to control the quality of these products.

\section{Acknowledgements}

We would like to thank Dr. Hafedh Driss Assistant Professor at King Abdulaziz University for his precious help in performing XRF and XRD experiment and analysis.

\section{Conflicts of Interest}

The authors declare no conflicts of interest regarding the publication of this paper.

\section{References}

[1] Brown, V. (2013) Metals in Lip Products-A Cause for Concern? Environmental Health Perspectives. Environmental Health Perspectives, 121, a196-106. https://doi.org/10.1289/ehp.121-a196

[2] Ungár, T., Martinetto, P., Ribárik, G., Dooryhée, E., Walter, P. and Anne, M. (2002) Revealing the Powdering Methods of Black Makeup in Ancient Egypt by Fitting Microstructure Based Fourier Coefficients to the Whole x-Ray Diffraction Profiles of Galena. Journal of Applied Physics, 91, 2455-2465. https://doi.org/10.1063/1.1429792

[3] Draize, J., Woodard, G. and Calvery, H. (1944) Methods for the Study of Irritation and Toxicity of Substances Applied Topically to the Skin and Mucous Membranes. Journal of Pharmacology and Experimental Therapeutics, 82, 377-390.

[4] Corbett, J., Sharma, R. and Dressler, W. (1999) Cosmetic Toxicology. Toxicology Academic Press, San Diego, 899-918. https://doi.org/10.1016/B978-012473270-4/50096-1

[5] Saeed, M., Muhammad, N. and Khan, H. (2011) Assessment of Heavy Metal Content of Branded Pakistani Herbal Products. Tropical Journal of Pharmaceutical Re- 
search, 10, 499-506. https://doi.org/10.4314/tjpr.v10i4.16

[6] Bernardi, R. (2002) Protect Children from the Dangers of Lead. US Department of Housing and Urban Development, Washington, 2-22.

[7] Al-Dayel, H. and Al-Ajyan, T. (1011) Human Exposure to Heavy Metals from Cosmetics. Oriental Journal of Chemistry, 27, 1-11.

[8] Ullah, H., Noreen, S., Rehman, A., Waseem, A., Zubair, S., Adnan, M. and Ahmad, I. (2013) Comparative Study of Heavy Metals Content in Cosmetic Products of Different Countries Marketed in Khyber Pakhtunkhwa, Pakistan. Arabian Journal of Chemistry, 10, 10-18. https://doi.org/10.1016/j.arabjc.2013.09.021

[9] Hepp, N., Mindak, W. and Cheng, J. (2009) Determination of Total Lead in Lipstick: Development and Validation of a Microwave-Assisted Digestion, Inductively Coupled Plasma-Mass Spectrometric Method. Journal of Cosmetic Science, 60, 405-415.

[10] Theresa, O., Onebunne, O., Dorcas, W. and Ajani, O. (2011) Potentially Toxic Metals Exposure from Body Creams Sold in Lagos. Researcher, 3, 30-37.

[11] Tsankov, I., Iordanova, I., Lolova, D., Uzunova, S. and Dinoeva, S. (1981) Hygienic Evaluation of the Content of Heavy Metals (Lead and Copper) in Cosmetic Products. Probl Khig, 7, 127-136.

[12] AI-Saleh, I. and Coate, L. (1995) Lead Exposure in Saudi Arabia from the Use of Traditional Cosmetics and Medical Remedies. Environmental Geochemistry and Health, 17, 29-31. https://doi.org/10.1007/BF00188629

[13] Volpe, M., Nazzaro, M., Coppola, R., Rapuano, F. and Aquino, R. (2012) Determination and Assessments of Selected Heavy Metals in Eye Shadow Cosmetics from China, Italy, and USA. Microchemical Journal, 101, 65-69.

https://doi.org/10.1016/j.microc.2011.10.008

[14] GSO 2170/2011 (2008) Determination of Heavy Metal (Arsenic, Cadmium, Lead and Mercury) in Cosmetic Products. Standards Organization for the Gulf Cooperation Council and Yemen.

[15] Barakat, M. (2011) New Trends in Removing Heavy Metals from Industrial Wastewater. Arabian Journal of Chemistry, 4, 361-367. https://doi.org/10.1016/j.arabjc.2010.07.019

[16] Sainio, E., Jolanki, R., Hakala, E. and Kanerva, L. (2000) Metals and Arsenic in Eye Shadows. Contact Dermatitis, 42, 5-10. https://doi.org/10.1034/j.1600-0536.2000.042001005.x

[17] Basketter, D., Briatico-Vangosa, G., Kaestner, W., Lally, C. and Bontinck, W. (1993) Nickel, Cobalt and Chromium in Consumer Products: A Role in Allergic Contact Dermatitis? Contact Dermatitis, 28, 15-25. https://doi.org/10.1111/j.1600-0536.1993.tb03318.x

[18] Allenby, C. and Basketter, D. (1993) An Arm Immersion Model of Compromised Skin. Contact Dermatitis, 28, 129-133. https://doi.org/10.1111/j.1600-0536.1993.tb03371.x

[19] Basketter, D., Angelini, G., Ingber, A., Kern, P. and Menné, T. (2003) Nickel, Chromium and Cobalt in Consumer Products: Revisiting Safe Levels in the New Millennium. Contact Dermatitis, 49, 1-7. https://doi.org/10.1111/j.0105-1873.2003.00149.x

[20] Söğüt, Ö., Reyhanlıoğlu, H., Ezer, M. and Baltaş, H. (2016) Elemental Compostions of Some Cosmetic Products Marketed in Turkey. Fresenius Environmental Bulletin, 25, 1068-1077. 